\title{
Old men hyperthyroidism
}

\author{
S Giuliano \\ From de Senectute: Age and Health Forum \\ Catanzaro, Italy. 5-7 December 2009
}

Even the thyroid, like all the other organs and tissues, has undergone anatomic-functional modifications during the senescence. One of the characteristics of ageing is the significant increase of thyroid disease and their different clinical expression. Moreover, thyroid disease in older patients requires special attention because of the increased gravity caused by the frequent co-existence of other pathologies or the greater risk of pharmacological interferences and a lower metabolism of the drugs. In particular, hyperthyroidism in old men is a pathology that should not be undervalued because of the peculiarity of the clinical and prognostic aspects which characterize this age.

The prevalence of hyperthyroidism increases 7 times in people over sixty-five years old and, including the subclinical hyperthyroidism; the percentage of people over sixty-five years old oscillates from $0,7 \%$ to $4 \%$ according to the casuistry.

The most frequent causes of hyperthyroidism in old men are the toxic multinodular goiter and the autonomously functioning solitary nodules, which in the iodineless areas represent over the $70 \%$ of the causes; moreover hyperthyroidism exogenous (iodine and iodathe composts, like amiodarone, means of radiological contrast, ingestion of intentional or unintentional suppressive doses of thyroid hormone).

The clinical manifestations of hyperthyroidism are peculiar and they are often different in old men with respect to young men.

In old men the apatetica production is frequent with not many aspecific symptoms and cardiovascular complications (atrial fibrillation or other arrhythmias).

Also the therapy is different in old men with respect to young men. In fact it must be individualized not only because of the causes, but also the age, by the risk

\footnotetext{
Unit of Endocrinology and Metabolic Diseases, University Hospital Mater
} Domini-Germaneto, Catanzaro, Italy factors of cardiovascular illnesses and by the presence of others illnesses, too.

Published: 19 May 2010

doi:10.1186/1471-2318-10-S1-L22

Cite this article as: Giuliano: Old men hyperthyroidism. BMC Geriatrics 2010 10(Suppl 1):L22.
Submit your next manuscript to BioMed Central and take full advantage of:

- Convenient online submission

- Thorough peer review

- No space constraints or color figure charges

- Immediate publication on acceptance

- Inclusion in PubMed, CAS, Scopus and Google Scholar

- Research which is freely available for redistribution

Submit your manuscript at www.biomedcentral.com/submit
C Biomed Central 